\title{
FILSAFAT ILMU SEBAGAI LANDASAN HOLISTIS PENGEMBANGAN ILMU PSIKOLOGI
}

\author{
Juneman; Yosef Dedy Pradipto \\ Psychology Department, Faculty of Humanities, BINUS University \\ Jln. Kemanggisan Ilir III No. 45, Kemanggisan-Palmerah, Jakarta Barat 11480 \\ juneman@binus.ac.id; ypradipto@binus.edu
}

\begin{abstract}
Psychology has long been accepted by many scholars as a science. Nevertheless, intensive readings on philosophy of science and psychology in Indonesia are rarely found. Meanwhile, there are not many professional psychologists nor psychology scientists deliver a course on Philosophy of Science in the faculties and study programs of psychology. The common argument proposed is that both psychologists and lecturers on psychology are not well qualified nor confident enough to teach the Philosophy of Science subject, as if the subject "is only taught" by philosophers or alumni of philosophy department. This phenomenon depicts that there are two worlds: the psychology world and the "other world", philosophy. This straight differentiation is certainly both unnecessary and dangerous as philosophy of science is indeed inherent in any psychological discussions. This article proposed that philosophy of science is a holistic base for the development of psychology and that the relationship between philosophy of science and psychology is close and tight. Psychologists are expected to take more part in inquiring assumptions and values in psychology and thus the simplification of psychology as a technical psychodiagnostic could be avoided.
\end{abstract}

Keywords: philosophy, science, psychology, philosopher, psychologist

\begin{abstract}
ABSTRAK
Psikologi adalah sebuah ilmu telah diterima oleh banyak pihak. Namun demikian, tulisan-tulisan yang mendiskusikan secara tandas dan elaboratif relasi antara filsafat ilmu dengan psikologi dalam teks berbahasa Indonesia masih langka. Di samping itu, dalam kenyataannya, belum banyak psikolog dan ilmuwan psikologi yang mengajarkan matakuliah Filsafat Ilmu di fakultas-fakultas dan program studi psikologi. Biasanya, alasan yang muncul di kalangan dosen adalah bahwa psikolog dan ilmuwan psikologi tidak berkualifikasi atau tidak percaya diri menjadi pengampu matakuliah ini, dan seolah-olah matakuliah ini hanya "lahan mengajar"-nya filsuf atau alumni pendidikan filsafat. Hal-hal tersebut memberikan gambaran bahwa ada satu dunia, yakni dunia psikologi, dan ada "dunia lain", yakni dunia filsafat. Pengotakan semacam ini bukan hanya tidak perlu, melainkan juga berbahaya karena sesungguhnya filsafat ilmu bersifat inheren dalam setiap pembahasan psikologis. Artikel ini mengajukan sebuah proposisi bahwa filsafat ilmu merupakan landasan holistis pengembangan ilmu psikologi, dan memperlihatkan betapa erat hubungan antar keduanya. Psikolog diajak untuk lebih banyak mengambil peran dalam memeriksa asumsi-asumsi pengetahuan dan nilai pengetahuan dalam psikologi, sehingga mampu menghindari jebakan simplifikasi psikologi sebagai teknik psikodiagnostik.
\end{abstract}

Kata kunci: filsafat, ilmu, psikologi, filsuf, psikolog 


\section{PENDAHULUAN}

Pernyataan Descartes (dalam Baird \& Kaufmann, 2008), "Cogito ergo sum!" menunjukkan aktivitas rasional sebagai identitas manusia. Itulah sebabnya manusia terus terdorong untuk mengembangkan seperangkat ilmu. Hal ini bersumber pada kenyataan bahwa ia memerlukannya. Manusia ditantang untuk menentukan sendiri bagaimana bersikap terhadap prasyarat-prasyarat kehidupannya. Oleh karena seluruh realitas secara potensial memengaruhinya, manusia sedemikian membutuhkan pengetahuan yang setepat-tepatnya dan selengkap-lengkapnya tentang seluruh realitas itu. Ia hanya dapat hidup dengan baik apabila ia menanggapi realitas itu sebagaimana adanya, dan untuk itu ia harus tahu, mengerti, dan memahaminya. Dari historisitasnya, filsafatlah yang menangani "pengetahuan" itu. Selanjutnya, pada permulaan zaman modern, filsafat dibandingkan dengan pohon yang meliputi seluruh ilmu (Descartes): akar-akarnya adalah metafisika, dan ranting-rantingnya adalah semua ilmu yang lain. Ilmu-ilmu tersebut satu per satu memperoleh otonominya, berkembang pesat, dan mengambil alih banyak tugas yang secara tradisional dijalankan filsafat.

Ilmu-ilmu tersebut meningkatkan kuantitas dan kualitas pengetahuan manusia. Ilmu-ilmu itu mengorganisasikan pengetahuan manusia secara sistematis agar efektif, dan mengembangkan metodemetode untuk menambah, memperdalam, dan membetulkannya. Demi tujuan itu, ilmu harus membatasi diri pada bidang-bidang tertentu dan mengembangkan metode-metode setepat mungkin untuk bidangnya masing-masing. Namun, pengkhususuan ([super-]spesialisasi) ilmu-ilmu—berkat positivisme-menjadi hal yang mendasari sukses pesatnya ilmu-ilmu itu, sekaligus merupakan keterbatasannya. Pertanyaan yang lebih umum, yang menyangkut beberapa bidang atau hubungan interdisipliner, pertanyaan mengenai realitas sebagai keseluruhan, mengenai manusia dalam keutuhannya, tidak dapat ditangani oleh ilmu-ilmu itu karena ilmu-ilmu itu tidak memiliki sarana teoretis untuk mambahasnya. Justru dalam hal ini diperlukan filsafat ilmu, untuk menangani pertanyaan-pertanyaan mahapenting yang di luar kemampuan metodis ilmu-ilmu spesial itu, secara metodis, sistematis, kritis dan berdasar.

Filsafat ilmu diperlukan untuk: (1) membantu membedakan ilmu dengan saintisme (yang memutlakkan berlakunya ilmu dan tidak menerima cara pengenalan lain selain cara pengenalan yang dijalankan ilmu), (2) memberi jawab atas pertanyaan"makna" dan "nilai", dalam hal mana ilmu membatasi diri pada penjelasan mekanisme saja (Bertens, 2005), (3) merefleksi, menguji, mengritik asumsi dan metode keilmuan, sebab ada kecenderungan penerapan metode ilmiah tanpa memperhatikan struktur ilmu itu sendiri (Mustansyir \& Munir, 2001), serta (4) dari hubungan historisnya dengan ilmu, filsafat menginspirasikan masalah-masalah yang akan dikaji oleh ilmu.

Berdasar seluruh uraian di atas, jelas kiranya hubungan filsafat dengan ilmu. Ringkasnya dapat dikatakan bahwa filsafat dengan tiga bidang utamanya-yakni metafisika (khususnya ontologi), epistemologi, dan aksiologi-merupakan landasan holistis pengembangan ilmu. Inilah hal yang merupakan tesis utama yang sekaligus juga menjadi kerangka tulisan ini. Pertama, dibicarakan metode pemerolehan pengetahuan ilmiah, sifat kebenaran yang dijamin serta batas-batas-batas pengetahuan sebagai konsekuensi metode itu (landasan epistomologis dari pihak filsafat ilmu). Kedua, dijelaskan hakikat isi penjelasan ilmiah yang membedakannya dengan yang non-ilmiah (ontology of scientific explanation). Ketiga, dipertanggungjawabkan argumentasi bahwa pengetahuan ilmiah tidak dapat digunakan sekehendak ilmuwan tanpa batas (landasan aksiologis).

Landasan epistemologis ilmu berkaitan dengan aspek-aspek metodologis ilmu dan sarana berpikir ilmiah lainnya, seperti bahasa, logika, matematika, dan statistika. Landasan ini berangkat dari suatu premis bahwa sesungguhnya alam semesta tidak berbicara (dalam arti formal); ia hanya memanifestasikan diri dalam dan lewat fakta-fakta saja. Agar sains dapat berada, metode-metode (mekanisme-mekanisme) tertentu harus diciptakan, untuk "menanyai" alam semesta dan bahkan untuk 
menerima darinya jawaban-jawaban yang signifikatif dan kondusif. Inilah fungsi pokok metode ilmiah yang akan dielaborasi lebih jauh nanti. Dalam konteks ini, hendak dijawab pula pertanyaan: (1) "Apakah ilmu menjamin diperolehnya kebenaran?", (2) "Apakah batas-batas pengetahuan ilmiah itu?"

Terhadap pertanyaan pertama, diajukan proposisi bahwa kebenaran itu bukanlah sesuatu yang stabil atau yang sudah ada, melainkan berada dalam sejarah yang senantiasa berubah. Dalam analogi ilustratif Leahy (2002: 17), "Kita naik selangkah demi selangkah dari suatu tangga yang panjang; sehingga dewasa ini kepada kita disajikan suatu perspektif yang dahulu tidak ada, dan yang memungkinkan kita untuk menentukan relasi-relasi antara segi-segi alam semesta." Di samping itu, sejarah ilmu menunjukkan bahwa para filsuf dan ilmuwan tidak mampu merumuskan perangkat ketentuan yang universal diterima semua orang untuk menilai kebenaran (Alsa, 2003). Dalam psikologi, hal ini berarti bahwa memahami satu sistem psikologi tertentu menuntut pengetahuan tentang kriteria kebenaran yang dianut oleh sistem tersebut. Dalam psikologi, kriteria itu misalnya: deductive explanation, behavioral control, interpretive consistency, intuitive knowing (Alsa, 2003: 3).

Argumentasi di atas semakin diperumit lagi apabila pemikiran Michel Foucault diikutsertakan, bahwa kebenaran pun ditunjuk dalam setiap wacana ilmiah di mana kuasa strategi dipraktikkan (Kebung, 2002). Demikian pula, kita dapat menjadi semakin pesimis mengenai penjaminan pemerolehan kebenaran oleh ilmu, apabila kita merujuk pada hipotesis Foucault bahwa sejarah pengetahuan tidak begitu saja patuh pada hukum umum kemajuan nalar. Di bawah apa yang diketahui oleh ilmu pengetahuan, ada sesuatu yang tidak diketahuinya, tetapi yang mempunyai hukum dan aturannya sendiri. Tidak mengherankan, Foucault memposisikan psikoanalisis (di samping etnologi) secara khusus, bukan karena berhasil menjadi ilmiah dengan memantapkan landasan positivitasnya, tetapi karena terus mempertanyakan segala sesuatu yang tampak mapan (Leksono, 2002: 31).

Berdasarkan uraian di atas, jelas bahwa yang dijamin untuk diperoleh oleh ilmu hanyalah jenis kebenaran ilmiah (scientific truth), meskipun sifat-sifatnya tidak mutlak, tidak samad, melainkan bersifat nisbi (relatif), sementara (tentatif), dan hanya merupakan pendekatan (Wilardjo dalam Suriasumantri, 1997: 239). "Kebenaran ilmiah" dalam tulisan ini diartikan sebagai kebenaran yang didapat melalui cara-cara baku yang disebut "metode ilmiah"; jadi, kebenaran yang didapat dengan cara lain tidak disebut kebenaran ilmiah, kecuali aksioma dalam matematika (Marzoeki, 2000). Ada kebenaran lain dan sumber kebenaran lain (filsafat, seni, agama, dsb) (Suriasumantri, 1997).

Versi terbaru atau mutakhir dari apa yang disebut "kebenaran ilmiah" itulah yang disebut sebagai "teori" (Alwasilah, 2002). Menurut Shaw dan Costanzo (dalam Sarwono, 2002), teori merupakan serangkaian hipotesis atau proposisi yang saling berhubungan tentang suatu gejala (fenomena) atau sejumlah gejala. Berdasarkan definisi ini, dapat disimpulkan sedikitnya empat fungsi teori: (1) menjelaskan atau memberi tafsir baru terhadap fenomena, (2) menghubungkan satu konsep/konstruk dengan konsep/konstruk lain, (3) memprediksi gejala, dan (4) menyediakan kerangka yang lebih jembar dari temuan dan pengamatan.

Metode ilmiahlah yang merupakan prosedur baku yang berfungsi menghasilkan teori/kebenaran dimaksud. Metode ilmiah merupakan rentetan daur-daur penyimpulan-rampatan (induksi), penyimpul-khasan (deduksi) dan penyahihan (verifikasi/validasi) yang terus menerus tak kunjung usai (Wilardjo dalam Suriasumantri, 1997). Dalam daur ini, terdapat demarkasi yang disebut Karl Popper sebagai falsifiabilitas. Yang harus melewati patok demarkasi pengujian empiris ini adalah hipotesis. Hipotesis merupakan pernyataan dugaan (conjectural) tentang hubungan antara dua variabel atau lebih, yang dapat dirunut atau dijabarkan dari teori dan dari hipotesis lain (Kerlinger, 2003). Apabila hipotesis kerja (yang hendak diuji) bertahan menghadapi semua usaha menolaknya sebagai keliru (false), teori baru (Popper: "system of hypotheses"; Shaw \& Costanzo: "a set of interrelated hypothesis") boleh dianggap sudah diperoleh. Jadi, fungsi hipotesis adalah mengarahkan prosedur penelitian ilmiah, dan membawa ilmuwan "keluar" dari dirinya sendiri (Kerlinger, 2003). Dua atau lebih variabel yang dijalinkan oleh hipotesis merupakan konstruk-konstruk atau konsep-konsep yang 
memiliki variasi nilai dan terhubung dengan realitas via pengukuran. "Konsep" mengungkapkan abstraksi yang terbentuk oleh generalisasi dari hal-hal khusus (Kerlinger, 2003), sedangkan "konstruk" merupakan konsep-konsep yang didefinisikan oleh sebuah jejaring nomologis, yang mengaitkan konstruk-konstruk dan variabel-variabel yang teramati melalui seperangkat relasi-relasi teoritis-sah (Cronbach \& Meehl, 1955). Menurut Bunge (1983), konstruk adalah sebuah objek ideal, yang eksistensinya bergantung (predicated) pada mind seseorang; dalam hal ini dikontraskan dengan objekobjek riil, yang eksistensinya tidak bergantung pada mind. Dalam definisi yang lain, konstruk merupakan sebuah properti mental (Hudgens, Dineen, Webster, Lai, \& Cella, 2004). Fungsi konsep adalah sebagai alat identifikasi fenomena yang diobservasinya (Effendi dalam Singarimbun \& Effendi, 2006); misalnya, "konsep prestasi akademis" mengungkapkan sejumlah observasi tentang hal-hal yang lebih atau kurang "prestatif". Sedangkan konstruk berfungsi membantu kita mengerti esensi fenomena yang sedang diteliti (Christensen, Johnson, \& Horn, 2008); misalnya, "konstruk prestasi" menolong kita mengenali kenyataan bahwa prestasi akademis merupakan fungsi dari inteligensi dan motivasi.

Suatu pernyataan teoretis mesti berlandaskan pada pernyataan sebelumnya. Pernyataan sebelumnya harus berlandaskan pernyataan sebelumnya lagi, dan seterusnya, sehingga kita dapat sampai pada pernyataan yang paling pangkal diajukan. Pernyataan ini dianggap terbukti dengan sendirinya (self-evident) dan diterima umum sebagai kebenaran (universally recognized as truth) disebut aksioma (Marzoeki, 2000). Contoh aksioma dalam Psikologi Sosial: (1) manusia mengkonstruksi realitasnya sendiri, dan (2) pengaruh-pengaruh sosial bersifat pervasif (Smith \& Mackie, 2000). Nampak bahwa fungsi aksioma adalah membantu ilmuwan untuk mengorientasikan aktivitas ilmiahnya secara tepat, sehingga data, penyelidikan, dan interpretasi menjadi harmonis dengan aksioma orisinalnya. Menurut Kantor (1983, h. 1), "No intellectual work can be organized into a system of interpretation and explanation without the operation of axioms as basic assumptions." Di samping itu, fungsi aktual aksioma adalah untuk menjelaskan fenomena yang dideskripsikan oleh teorema-teorema dari sebuah sistem ilmu (Lakatos, 1978).

Selanjutnya, terhadap pertanyaan epistemologis kedua, dapat dikemukakan bahwa para ahli sejarah sains dan metodologi ilmiah mengakui adanya jenis masalah yang, meskipun lahir dari dalam sains, namun melampaui batas-batas sains itu (Leahy, 1997), misalnya: (1) Ahli fisika, yang menghadapi soal hubungan antara subjek dan objek, yang bersifat filosofis; (2) Ahli biologi, yang menemui program DNA, seakan-akan materi "dipikirkan" ke arah prestasi yang melampaui kemampuan materi murni; (3) Kasus Hellen Keller, yang menunjukkan bahwa semua usaha untuk merendahkan kesadaran intelektual kepada derajat suatu psikologi empiris atau sensualis saja, sama sekali kalah. Kasus ini tidak dapat dimengerti tanpa melihat dalam inteligensi sebuah dimensi yang memang supra-material.

Berdasarkan contoh-contoh di atas, dapat disimpulkan bahwa pengetahuan ilmiah itu terbatas setidaknya berdasarkan dua argumen pokok: (1) keterbatasan persepsi, memori, dan penalaran, (2) implikasi saintifik kosmos terhadap pertanyaan-pertanyaan paripurna. Pertama, kiranya sudah sangat jelas bahwa persepsi, ingatan, dan penalaran sebagai sumber pemerolehan pengetahuan manusia mempunyai kelemahan-kelemahan (Suriasumantri, 1997). Dalam kaitan ini, kegiatan berpikir dalam ilmu menggunakan objek-objek material berupa gejala-gejala konkret yang dapat diamati secara langsung (Takwin, 2003), dan pun sehubungan dengan ini, Tennant (1968: 364) menyatakan:

Science can only know .... the Real through and as the phenomenal. It is precluded from making statements, positive or negative, as to the ontal, and from claiming absolute knowledge or non-phenomenal knowledge of the absolute.

Kedua, terdapatnya batas-batas pengetahuan ilmiah justru mendasarkan diri secara paradoksikal pada sebuah asumsi sebagaimana dinyatakan oleh Paul Davis (dalam Leahy, 2002: 15): 
Seluruh bangunan ilmiah berdasarkan hipotesis rasionalitas alam semesta ... Sukses sains setidaknya merupakan suatu evidensi tak langsung (circumstantial evidence) bagi rasionalitas alam semesta.

Paradoksnya adalah bahwa rasionalitas alam semesta yang ditunjukkan oleh sains menjadi jembatan yang menghubungkan sains itu sendiri-yang sadar batas-batas pengetahuannya-dengan masalahmasalah paripurna mengenai "makna" yang tinggal jauh di luar ilmu-ilmu empiris.

Landasan ontologis ilmu berkaitan dengan hakikat ilmu; secara ontologis, ilmu mengkaji realitas sebagaimana adanya (das Sein). Persoalan yang didalami: "Apakah yang menjadi bidang telaah ilmu?" Dalam konteks ini, hendak dijawab pula pertanyaan: "Apakah yang membedakan penjelasan ilmiah dengan penjelasan lainnya?". Berdasarkan uraian sebelumnya, jelas bahwa terdapat tiga hal distingtif penjelasan ilmiah (scientific explanation): (1) deduktif, (2) probabilistik, (3) fungsional atau teleologis, dan yang keempat, menurut Ernest Nagel (dalam Suriasumantri, 2000: 142143), adalah (4) genetik.

Contoh: Penjelasan probabilistik ditarik secara induktif dari sejumlah kasus yang dengan demikian tidak memberikan kepastian seperti penjelasan deduktif, melainkan penjelasan yang bersifat peluang, seperti "kemungkinan", "kemungkinan besar", atau "hampir dapat dipastikan". Penjelasan fungsional atau teleologis meletakkan sebuah unsur dalam kaitannya dengan sistem secara keseluruhan yang mempunyai karakteristik atau arah perkembangan tertentu (Suriasumantri, 2000: 142).

Dewasa ini telah ditemukan model-model penjelasan ilmiah yang membedakannya dengan penjelasan non-ilmiah, yakni Deductive-Nomological (DN), Statistical Relevance (SR), Causal Mechanical (CM), dan Unificationist models ("Scientific explanation", 2009). Dalam model DN, sebagai contoh, ilmu bertanggung jawab untuk menyediakan jawaban yang memuaskan atas pertanyaan "mengapa". Suatu jawaban atas pertanyaan "mengapa" baru dapat disebut penjelasan ilmiah apabila ia memiliki struktur yang logis dalam argumennya, yaitu terdiri atas premis-premis dan kesimpulan yang memiliki relasi satu sama lain. Kesimpulan yang ada di dalamnya merupakan fenomena yang perlu dijelaskan (explanandum), sedangkan premis-premisnya adalah fakta yang bisa digunakan untuk mendukung kesimpulan tersebut (explanans). Untuk dapat memberikan penjelasan, ilmu memiliki argumen deduktif dengan minimal satu hukum umum sebagai premis dan satu explanandum sebagai konklusi. Explanans memberikan penjelasan ilmiah terhadap explanandum hanya apabila: (1) Explanandum merupakan konsekuensi logis dari konjungsi explanans; (2) Tidak ada surplus explanans yang tidak perlu dalam rangka eksplanasi; (3) Pernyataan-pernyataan explanans harus memiliki isi empiris; (4) Semua pernyataan explanans harus benar (Ruben, 1990). Ada karakteristik lain dari model DN, yaitu bahwa sebuah eksplanasi dapat digunakan untuk memperkirakan, dan sebuah prediksi adalah sebuah eksplanasi yang sah karena kepersisan struktur logisnya. Model ini sangat jelas membedakan antara ilmu dan bukan-ilmu.

Landasan aksiologis ilmu berkaitan dengan dampak ilmu bagi umat manusia. Pertanyaan yang menjadi persoalan utama di sini adalah: "Apa manfaat (untuk apa) ilmu bagi manusia?" (dalam psikologi, lihat juga "The New Science of Axiological Psychology" oleh Leon Pomeory). Dalam konteks ini, dapat ditambahkan pertanyaan: "Sejauh mana pengetahuan ilmiah dapat digunakan?". Dalam hal ini, persoalannya bukan lagi kebenaran, melainkan kebaikan. Secara epistemologis, persoalan ini berada di luar batas pengetahuan sains. Menurut Bertens (dalam Magnis-Seseno dkk., 1992), pertanyaan ini menyangkut etika: "Apakah yang bisa dilakukan berkat perkembangan ilmu pengetahuan, pada kenyataannya boleh dipraktikkan juga?". Pertanyaan aksiologis ini bukan merupakan pertanyaan yang dijawab oleh ilmu itu sendiri, melainkan harus dijawab oleh manusia di balik ilmu itu. Jawabnya adalah bahwa pengetahuan ilmiah harus dibatasi penggunaannya, yakni sejauh ditentukan oleh kesadaran moral manusia. Menurut Magnis-Suseno (1995: 60-61), "Ilmuwan tidak pernah boleh semata-mata merupakan ilmuwan." Ilmuwan harus mengembangkan suatu 
tanggungjawab sosial, dengan tidak begitu saja melepaskan kekuatan-kekuatan yang kemudian tidak dapat dikuasai manusia lagi. Menurut Bertens (1992, 2001), pembatasan (sejauh mana) penggunaan pengetahuan ilmiah menuntut penanganan yang menyeluruh, yang biasanya ditetapkan oleh negara (biomedis), perjanjian internasional (persenjataan nuklir), atau komisi-komisi etis. Hal ini karena individu-individu ilmuwan itu sendiri tidak berdaya menangani masalah-masalah etis, khususnya yang berat. Namun, jadi, sejauh mana hak kebebasan untuk meneliti? Hal ini merupakan permasalahan yang pelik.

\section{SIMPULAN}

Kekayaan reflektif manusia, lewat olah nalar, menghasilkan pengetahuan yang dikembangkan dengan tata kelola keilmiahan, menjadi ilmu pengetahuan seperti psikologi. Labirin spiral ulang-alik olah pikir ini menjadi tajam dan mendalam karena filsafat ilmu. Rasio, intelektual, ide dan aktivitas penalaran di tataran wacana yang berangkat dari pengalaman di aras praksis, telah menghatar manusia pada pergumulan teoritis yang menelurkan pengetahuan namun tetap merupakan upaya manusia dan manusiawi sepanjang masa. Formulasi pengetahuan seturut tata kelola ilmiah distimulasi oleh dan dari fenomena humanis. Merupakan sebuah keniscayaan melepas rasa, asa dan nurani dalam seluruh proses tersebut. Selain itu tetap ada misteri dalam belantara pengetahuan dan ilmu psikologi.

Melalui filsafat pula menjadi disadari bahwa semua dan seluruh proses tersebut membutuhkan etika. Kebenaran mutlak perlu dicintai dengan kebijaksanaan yang dituntut oleh moralitas yang mengusung harkat manusia dan Sang Pencipta. Etika dan moralitas menghantar manusia pada fitrahnya untuk menjadi rendah hati sebagai ciptaan Sang Khalik. Justru dalam konteks keseluruhan pembahasan itulah, filsafat pada umumnya dan filsafat ilmu pada khususnya merangsang dan menunjang pertumbuhan psikologi sebagai sebuah ilmu.

\section{DAFTAR PUSTAKA}

Alsa, A. (2003). Pendekatan kuantitatif dan kualitatif serta kombinasinya dalam penelitian psikologi. Yogyakarta: Pustaka Pelajar.

Alwasilah, A. C. (2002). Pokoknya kualitatif. Jakarta: Pustaka Jaya.

Baird, F. E., \& Kaufmann, W. (2008). From Plato to Derrida. Upper Saddle River, New Jersey: Pearson Prentice Hall.

Bertens, K. (1992). Umat Katolik dan bioetika. Dalam Magnis-Suseno, F., Lajar, L. L., Bertens, K., Bagus, L., \& Mardiatmadja, B. S., Iman dan ilmu: Refleksi iman atas masalah-masalah aktual. Yogyakarta: Kanisius.

Bertens, K. (2001). Etika. Jakarta: Gramedia Pustaka Utama.

Bertens, K. (2005). Panorama filsafat modern (Edisi revisi). Jakarta: Teraju.

Bunge, M. A. (1983). Epistemology \& methodology. Hingham, MA: Reidel.

Christensen, C. M., Johnson, C., \& Horn, M. (2008). Disrupting class: How disruptive innovation will change the way the world learns. New York: McGraw-Hill. 
Cronbach, L. J., \& Meehl, P. E. (1955). Construct validity in psychological tests. Psychological Bulletin, 52(4), 281-302.

Hudgens, S., Dineen, K., Webster, K., Lai, J. S., \& Cella, D. (2004). Assessing statistically and clinically meaningful construct deficiency/saturation: Recommended criteria for content coverage and item writing. Rasch Measurement Transactions, 17(4). Ditemukembali pada 7 November 2009, dari http://www.rasch.org/rmt/rmt174.pdf

Kantor, J. R. (1983). Axioms and their role in psychology. Revista Mexicana de Análisis de la Conducta, 7(1), 5-11.

Kebung, K. (2002, Januari-Februari). Kembalinya moral melalui seks. Basis, No. 01-02, Th. 51, 3241.

Kerlinger, F. N. (2003). Asas-asas penelitian behavioral. Yogyakarta: Gadjah Mada University Press.

Lakatos, I. (1978). Mathematics, science and epistemology. Philosophical Papers, 2.

Leahy, L. (1997). Sains dan agama dalam konteks zaman ini. Yogyakarta: Kanisius.

Leahy, L. (2002). Horizon manusia: Dari pengetahuan ke kebijaksanaan. Yogyakarta: Kanisius.

Leksono, K. (2002, Januari-Februari). Berakhirnya manusia dan kebangkrutan ilmu-ilmu. Basis, No. 01-02, Th. 51, 22-31.

Magnis-Suseno, F. (1995). Filsafat-kebudayaan-politik: Butir-butir pemikiran kritis. Jakarta: Gramedia Pustaka Utama.

Marzoeki, D. (2000). Budaya ilmiah dan filsafat ilmu. Jakarta: Grasindo.

Mustansyir, R, \& Munir, M. (2001). Filsafat ilmu. Yogyakarta: Pustaka Pelajar.

Pomeory, L. (2005). The new science of axiological psychology. Amsterdam: Rodopi.

Ruben, D. (1990). Explaining explanation. London \& New York: Routledge.

Sarwono, S. W. (Ed.) (2002). Teori-teori psikologi sosial (Edisi revisi). Jakarta: RajaGrafindo Persada.

Scientific explanation. (2009, 16 Januari). Standford Encyclopedia of Philosophy. Ditemukembali pada 7 November 2009, dari http://plato.stanford.edu/entries/scientific-explanation/

Singarimbun. M., \& Effendi, S. (Ed.) (2006). Metode penelitian survai (Edisi revisi). Jakarta: LP3ES.

Smith, E. R., \& Mackie, D. M. (2000). Social psychology. Psychology Press.

Suriasumanti, J. (Ed.) (1997). Ilmu dalam perspektif: Sebuah kumpulan karangan tentang hakekat ilmu. Jakarta: Yayasan Obor Indonesia.

Suriasumantri, J. (2000). Filsafat ilmu: Sebuah pengantar populer. Jakarta: Pustaka Sinar Harapan. 
Takwin, B. (2003). Filsafat Timur: Sebuah pengantar ke pemikiran-pemikiran Timur. Yogyakarta \& Bandung: Jalasutra.

Tennant, F. R. (1968). Philosophical theology. London, N.W.: Cambridge University Press.

Wilardjo. L. (1997). Ilmu dan humaniora. Dalam Suriasumanti, J. (Ed.), Ilmu dalam perspektif: Sebuah kumpulan karangan tentang hakekat ilmu. Jakarta: Yayasan Obor Indonesia. 